\section{Phenylketonuria masked by low protein feeds}

Breast milk or low protein artificial feeds alone are recommended for infants in their first 4 months (Department of Health and Social Security, 1974). Use of these milks has caused difficulties in the diagnosis of phenylketonuria (PKU) requiring treatment, as illustrated by 2 cases.

\section{Case reports}

Case 1. A boy, birthweight $3.8 \mathrm{~kg}$, was breast fed apart from occasional feeds with Gold Cap SMA (Wyeth). Phenylalanine levels, estimated on blood spots by fluorimetric analysis were:

\begin{tabular}{lcc}
\hline Age $(d)$ & $\begin{array}{l}\text { Blood phenylalanine } \\
(\mu \mathrm{mol} / \mathrm{l})\end{array}$ & $(\mathrm{mg} / 100 \mathrm{ml})$ \\
\hline 6 & 587 & $9 \cdot 7$ \\
11 & 1022 & $16 \cdot 9$ \\
12 & 847 & $14 \cdot 0$ \\
22 & 1022 & $16 \cdot 9$ \\
\hline
\end{tabular}

Urine contained excess phenylpyruvic acid and its derivatives by gas-liquid chromatography. On the 24th day (due to the proximity of Christmas) treatment was started with a low phenylalanine diet of $65 \mathrm{mg} / \mathrm{kg}$. Phenylalanine levels less than $300 \mu \mathrm{mol} / 1$ $(5 \mathrm{mg} / 100 \mathrm{ml})$ were subsequently detected. At 3 months challenge with normal full-cream milk for 36 hours produced blood phenylalanine levels of $1391 \mu \mathrm{mol} / 1(23 \mathrm{mg} / 100 \mathrm{ml})$ and $1512 \mu \mathrm{mol} / 1(25 \mathrm{mg} /$ $100 \mathrm{ml})$. Now at the age of 1 year adequate control is achieved on an intake of $350 \mathrm{mg}$ phenylalanine per day and development is normal.

Both parents were heterozygotes as judged by noon plasma phenylalanine/tyrosine ratio plotted against phenylalanine concentration according to the method of Scriver and Rosenberg (1973).

Case 2. A boy, birthweight $3.25 \mathrm{~kg}$, received breast milk and subsequently Gold Cap SMA until the age of 18 weeks when mixed feeds were started. Blood phenylalanine levels were:

\begin{tabular}{lll}
\hline Age & $(\mu m o l / l)$ & $(\mathrm{mg} / 100 \mathrm{ml})$ \\
\hline $6 \mathrm{~d}$ & 424 & 7 \\
$7 \mathrm{w}$ & 696 & $11 \cdot 5$ \\
$18 \mathrm{w}$ & 708 & $11 \cdot 7$ \\
$29 \mathrm{w}$ & & \\
before feed & 1004 & $16 \cdot 6$ \\
after feed & 1488 & $24 \cdot 6$ \\
30 w (on Cow and Gate V Formula) & \\
morning & 847 & $14 \cdot 0$ \\
evening & 1119 & $18 \cdot 5$ \\
morning & 877 & $14 \cdot 5$ \\
evening & 744 & $12 \cdot 3$ \\
\hline
\end{tabular}

At 30 weeks a phenylalanine load test was carried out (Fig.) and the urine contained excess phenylpyruvic acid and its derivatives. Development was normal. A low phenylalanine diet was started, and on $350 \mathrm{mg}$ phenylalanine per day the blood level ranges around $300 \mu \mathrm{mol} / 1(5 \mathrm{mg} / 100 \mathrm{ml})$.

Both parents were heterozygotes by noon plasma estimations as in Case 1, but the mother was taking oral contraceptives. Additional confirmation of her heterozygous state was obtained by giving $100 \mathrm{mg}$ phenylalanine/kg orally which produced an excess excretion of $o$-hydroxyphenylacetic acid.

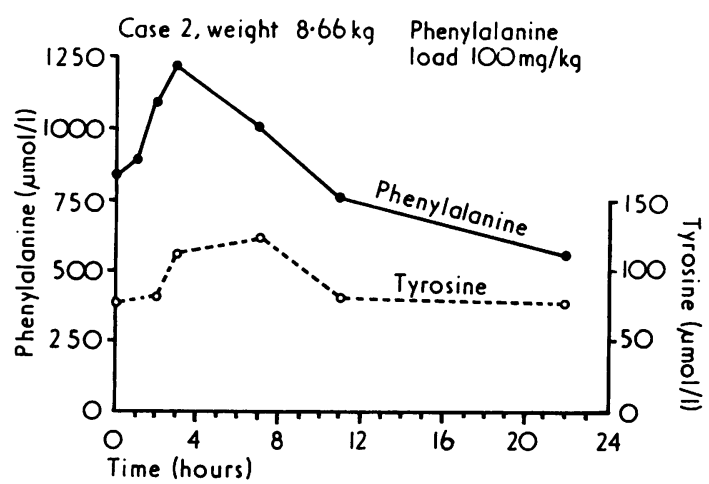

Fig. Blood phenylalanine and tyrosine levels after a phenylalanine load in Case 2.

Conversion: SI to traditional units-Phenylalanine:

$60 \mu \mathrm{mol} / \mathrm{l} \approx 1 \mathrm{mg} / 100 \mathrm{ml}$.Tyrosine: $55 \mu \mathrm{mol} / \mathrm{l} \approx$ $1 \mathrm{mg} / 100 \mathrm{ml}$.

\section{Discussion}

Both Cases 1 and 2 require a low phenylalanine diet to control their blood phenylalanine level, though the blood phenylalanine and tyrosine response to phenylalanine load in Case 2 makes the diagnosis of classic PKU doubtful. Both received low-protein milks and their phenylalanine levels did not rise above $1200 \mu \mathrm{mol} / 1(20 \mathrm{mg} / 100 \mathrm{ml})$, as usually happens in classical PKU, until they were given normal milk, a mixed diet, or a phenylalanine load. In 1971 and 1972 no cases of PKU were diagnosed in the UK after age 4 months (Hawcroft and Hudson, 1974), yet Case 2 will spoil the record for 1975 .

The protein content of milk feeds for babies has been extensively tabulated (Department of Health and Social Security, 1974) but the considerable variation in the phenylalanine content of the protein is not always appreciated. Cows' milk protein contains $5 \cdot 12 \mathrm{~g}$ phenylalanine/100 $\mathrm{g}$ (McCance and Widdowson, 1960), whereas whey proteins contain 
considerably less, about $3 \mathrm{~g} / 100 \mathrm{~g}$ depending upon the method of preparation (Forsum and Hambraeus, 1972). The phenylalanine content of mature breast milk protein is $4 \mathrm{~g} / 100 \mathrm{~g}$, while that of colostrum is $4 \cdot 8 \mathrm{~g} / 100 \mathrm{~g}$ (McCance and Widdowson, 1960).

Table 1 Phenylalanine content of infant milk feeds (manufacturer's data)

\begin{tabular}{ll}
\hline & $m g / l$ \\
\hline Mature breast milk & 410 \\
Cow \& Gate Premium & 560 \\
Gold Cap SMA & 630 \\
SMA \& Gate Babymilk Plus \\
Cow \& Gate V Formula \\
$\left.\begin{array}{l}\text { Cow \& G } \\
\text { Ostermilk Complete Formula }\end{array}\right\}$ \\
$\begin{array}{l}\text { Cow \& Gate Babymilk 1 (Half Cream) } \\
\text { Cow \& Gate Babymilk 2 (Full Cream) }\end{array}$ \\
$\begin{array}{l} \\
\text { Ostermilk No. 2 }\end{array}$ \\
\hline
\end{tabular}

Table 1 shows the phenylalanine content of mature breast milk and some commercial infant milk feeds available in the UK. This does not, however, take into account the variability of breast milk protein and phenylalanine which is shown in Table 2 .

Table 2 Protein and phenylalanine content of breast milk (data from Macy and Kelly, 1961)

\begin{tabular}{|c|c|c|c|c|c|c|}
\hline & \multicolumn{3}{|c|}{ Protein $(g / l)$} & \multicolumn{3}{|c|}{$\begin{array}{l}\text { Phenylalanine } \\
(m g / l)\end{array}$} \\
\hline & Mean & Min & $\operatorname{Max}$ & Mean & Min & $\operatorname{Max}$ \\
\hline $\begin{array}{l}\text { Colostrum } \\
\text { Transitional (5-15 d) } \\
\text { Mature }(15 \mathrm{~d}+)\end{array}$ & $\begin{array}{l}23 \\
16 \\
11\end{array}$ & $\begin{array}{r}15 \\
13 \\
7\end{array}$ & $\begin{array}{l}68 \\
19 \\
20\end{array}$ & $\begin{array}{r}1040 \\
630 \\
410\end{array}$ & $\begin{array}{l}600 \\
480 \\
300\end{array}$ & $\begin{array}{r}3770 \\
740 \\
580\end{array}$ \\
\hline
\end{tabular}

Infants completely fed on mature breast milk with an intake of $150 \mathrm{ml} / \mathrm{kg}$ per day will receive on average a phenylalanine intake of $61 \mathrm{mg} / \mathrm{kg}$ and some as little as $45 \mathrm{mg} / \mathrm{kg}$. These figures are similar to those used to calculate initial phenylalanine intakes in infants with PKU.

The effectiveness of PKU screening in the UK in breast-fed infants is due to the high phenylalanine in colostrum and transitional milk. Miller et al. (1950) measured the daily secretion of phenylalanine over the first 10 days of life by a microbiological assay. Only one of their measurements was less than $500 \mathrm{mg} / \mathrm{l}$ and this was on the 7th day. In infants who are completely breast fed, screening carried out after the second week may be misleading and a subsequent fall of phenylalanine may be due to reduced phenylalanine intake in cases of PKU rather than transient neonatal enzyme defects.

The first phenylalanine estimation in Case 2 was only $424 \mu \mathrm{mol} / 1(7 \mathrm{mg} / 100 \mathrm{ml})$ on the 6 th day, which is the lowest level we have seen in PKU requiring treatment. In Bristol, all patients with an initial phenylalanine level above $480 \mu \mathrm{mol} / 1(8 \mathrm{mg} / 100 \mathrm{ml})$ have been immediately investigated, and those with levels above $240 \mu \mathrm{mol} / 1(4 \mathrm{mg} / 100 \mathrm{ml})$ have been retested at 6 weeks of age. If at 6 weeks the level is above $480 \mu \mathrm{mol} / 1(8 \mathrm{mg} / 100 \mathrm{ml})$, fuller investigation is recommended. Experience of Case 2 suggests that the initial screening level for immediate retesting should be lowered unless tyrosine is estimated simultaneously. A significantly increased tyrosine will indicate transient tyrosinaemia.

We conclude the following. (1) All forms accompanying screening tests for PKU should state the milk feeds. This is already requested in the South West Region (but for different reasons). (2) Initial phenylalanine levels above $360 \mu \mathrm{mol} / 1(6 \mathrm{mg} / 100 \mathrm{ml})$ in the absence of associated tyrosinaemia require careful follow-up, particularly if the infant is fed with breast milk or a low protein milk. Under these circumstances the maximal phenylalanine level may be determined by a phenylalanine challenge.

\section{Summary}

Two patients with phenylketonuria (PKU) requiring treatment were fed on low protein milks. Both had blood phenylalanine levels below $1200 \mu \mathrm{mol} / 1(20 \mathrm{mg} /$ $100 \mathrm{ml}$ ) until given a phenylalanine challenge.

Phenylalanine content of mature breast milk may provide intakes similar to those used in treating PKU. Diagnosis of PKU is unlikely to be missed if screening is carried out on the sixth or seventh day of life because of higher phenylalanine in breast milk during the first week. Interpretation of screening tests requires knowledge of the infants' feeds and a blood phenylalanine above $360 \mu \mathrm{mol} / 1(6 \mathrm{mg} / 100 \mathrm{ml})$ in the absence of tyrosinaemia requires careful investigation.

\section{References}

Department of Health and Social Security (1974). Presentday Practice in Infant Feeding. Report on Health and Social Subjects No. 9. HMSO, London.

Forsum, E. F., and Hambraeus, L. (1972). Biological evaluation of a whey protein fraction with special reference to its use as a phenylalanine-low protein source in the dietary treatment of phenylketonuria. Nutrition and Metabolism, $14,48-62$.

Hawcroft, J., and Hudson, F. P. (1974). Screening for phenylketonuria in the United Kingdom. Health Trends, 6, 72-74.

McCance, R. A., and Widdowson, E. M. (1960). The Composition of Foods. MRC Special Report Series No. 297. HMSO, London.

Macy, I. G., and Kelly, H. J. (1961). Human milk and cow's milk in infant nutrition. Milk: The Mammary Gland and its Secretions, Vol. 2, p. 265. Ed. by S. K. Kon and A. T. Cowie. Academic Press, New York. 
Miller, S., Ruttinger, V., Rutledge, M. M., Frahm, R., Maurer, S., Moyer, E. Z., Kaucher, M., and Macy, I. G. (1950). Human milk studies: essential amino acids in human colostrum and transitional milk. Journal of Nutrition, 40, 499-514.

Scriver, C. R., and Rosenberg, L. E. (1973). Amino Acid Metabolism and its Disorders, p. 320. Saunders, Philadelphia.

David Burman,* John Holton, and John Allen Bristol Royal Hospital for Sick Children and Department of Clinical Chemistry, Southmead Hospital, Bristol.

*Correspondence to Dr D. Burman, Bristol Royal Hospital for Sick Children, St. Michael's Hill, Bristol BS2 8BJ.

\section{Conservative treatment of a BCG osteomyelitis of the femur}

BCG osteomyelitis and arthritis after BCG vaccination are rare considering the large number of newborns vaccinated (Foucard and Hjelmstedt, 1971). An unequivocal diagnosis can be obtained only by biopsy and bacteriological and histological examination (Paisseau et al., 1941; Backman and Wallgren, 1954; Felländer, 1963; Foucard and Hjelmstedt, 1971). The case presented here was diagnosed on clinical and radiographical criteria. Conservative tuberculostatic treatment was successfully applied. No surgical treatment was necessary.

\section{Case report}

The patient, a 3-year-old boy born to healthy parents after a normal pregnancy and birth, was vaccinated with BCG intracutaneously in the neonatal period without adverse reaction. He had never been seriously sick and had no known tuberculous contact in his family. 2 months before admission to hospital he slightly injured his right knee, after which he complained of pain in the right thigh and started to limp. Total blood counts and ESR at that time were normal. Antibiotics were given, but 6 weeks after the trauma slight erythema of the right knee appeared with local swelling and tenderness but no impairment of movement.

On examination at our clinic a number of enlarged though not tender lymph nodes were noted in the groin in addition to the above findings. Temperature was $37.4^{\circ} \mathrm{C}$ and ESR $15 \mathrm{~mm}$ in one hour. Radiographs of the right knee (Fig. 1) showed a round, localized osteolytic lesion in the metaphysis of the

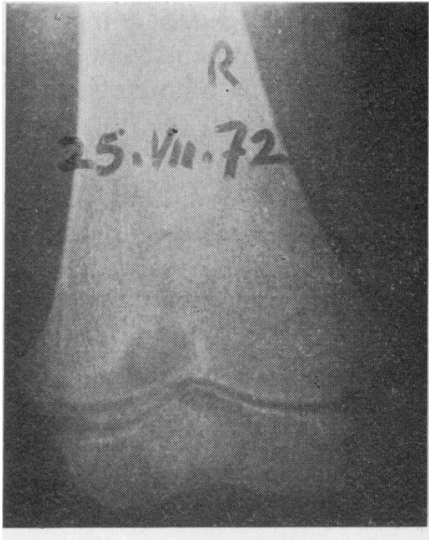

(a)

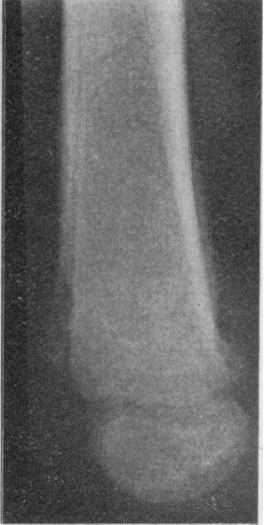

(b)
Fig. 1 (a) Osteolytic lesion in right lateral femoral condyle bordering epiphyseal plate. (b) Note periosteal reaction.

femur, bordering the distal epiphyseal plate, with a periosteal reaction in the supracondylar area. Treatment consisted of immobilization and large doses of antibiotics. 2 weeks later neither clinical nor radiological improvement was evident. At this time the ESR was $20-30 \mathrm{~mm}$ in one hour, $\mathrm{Hb} 14 \cdot 1$ $\mathrm{g} / \mathrm{dl}$, WBC $6 \cdot 8 \times 10^{9} / 1\left(6800 / \mathrm{mm}^{3}\right)(2 \mathrm{stab}, 61$ polynuclears, 33 lymphocytes, 1 eosinophil, 3 mononuclears), blood glucose $4.5 \mathrm{mmol} / 1(82 \mathrm{mg} / 100 \mathrm{ml})$, and urea $3.8 \mathrm{mmol} / \mathrm{l}(23 \mathrm{mg} / 100 \mathrm{ml})$. Mantoux test was positive $1: 1000$. $X$-ray examination of the right knee showed no further progression. A chest and skeletal survey were negative with no evidence of other foci.

The lesion seemed to be an infection of low virulence. Since there was no regression after massive antibiotic treatment (effective against Gram-positive cocci) and fewer than 4 years had elapsed since the BCG vaccination, BCG osteomyelitis of the femur was suspected. Because of the slow progression it was decided to carry out a trial treatment with tuberculostatic drugs alone. Sodium paraaminosalicylic acid $2 \mathrm{~g} / \mathrm{d}$, isoniazide $75 \mathrm{mg} / \mathrm{d}$, and streptomycin intramuscularly twice weekly were given for a period of 2 months. 5 weeks after treatment began the boy still had a slight limp but did not complain of pain. $X$-ray examination showed that the periosteal reaction had disappeared (Fig. 2). A month later the limp had also gone and treatment was stopped. When last seen $3 \frac{1}{2}$ years later he had no symptoms or signs. A radiograph of the femur showed a normal bone structure, no periosteal reaction, and the epiphyseal plate undamaged. 